\title{
Ecosystem Services and Recreational Values as Building Blocks for Eco Development in NATURA 2000 Sites
}

\author{
Judita Tomaskinova*, Jan Tomaskin, Petra Soporska \\ Matej Bel University in Banska Bystrica, Faculty of Natural Sciences, Department of Environment, \\ Banska Bystrica, Slovakia
}

Received: 18 February 2018

Accepted: 27 April 2018

\begin{abstract}
This paper reports the results of research aimed at assessing the recreational value (in the context of cultural value) of SCI Vtáčnik (central Slovakia), which is visited by about 16,000 tourists per year. The questionnaire survey was conducted from April to October 2015. The return rate of the questionnaire was $61.8 \%$ (309 respondents) out of 500 distributed copies consisting of 24 questions each. Following the processing of the results using the method of travel costs, with an average duration of stay of 1.38 day and respondents' costs of $€ 51.25$ per person/per stay, the total recreational value was calculated at $€ 820.051,2$. The overall ecosystem assessment services of the evaluated protected area result from recreational activities estimated at $€ 81.54$ when converted to 1 ha of total area of SCI Vtáčnik. Recreational value (VTR) just setting off costs directly linked to visits of the protected area is $€ 212.188,8$, and in recalculation on 1 ha of the total area a value of $€ 21.10$ was obtained.
\end{abstract}

Keywords: ecosystem services, recreational values, SCI Vtáčnik, WTP, VTR

\section{Introduction}

The Intergovernmental Platform on Biodiversity and Ecosystem Services (IPBES) now explicitly recognizes 'good quality of life' as the core of its conceptual framework [1]. Constanza et al. [2] and Turner and Daily [3] argue that 'capital' in the widest sense of the word, i.e., human, built, social, and natural capital, is a useful framework for conceptualizing the factors that shape well-being. While we are aware that the notion of 'capital' may not suit well-being discussions in all policy

*e-mail: tomaskinova@gmail.com contexts [4], here we follow the large body of literature that uses different forms of 'capital' beyond traditional economics (human, natural, social, built capital) in different forms as a way of describing links between people, the environment, and quality of life [5].

Large amounts of research have been conducted to develop a framework for measuring and valuing provisioning, supporting, regulating, and cultural ecosystem services (ES), and for linking this to biodiversity conservation, land use, and landscape management [6-13]. The ecosystem services framework (ESF) is based on a useful and holistic approach for analysing and comparing values and benefits associated with environments and natural resources. The ESF originated as an awareness-raising tool to illustrate 
societal dependence on ecological life support systems, then became an ecological-economic way of valuing environmental assets (natural capital) and services, and is increasingly being linked to concepts like well-being, quality of life, and identity [14-17]. Cultural ecosystem services address human welfare and rank high on the list of reasons for conservation and sustainable management of ecosystems [10, 18]. Non-economic and non-market values can stem from different types of ecosystem services, but tend to be lumped into cultural services as a residual category, which often renders them elusive [19]. In addition, the conflation of goods, services, benefits, and values, and the consequent inability to treat diverse kinds of values (e.g., market and non-market), complicates decision-making [18].

Assessing the value of ecosystem services of protected areas relates to an innovative way of nature and landscape management. The purpose of the evaluation is to point out their importance; it is possible to achieve their maximization by suitable adjustment and effectively incorporating management measures.

Ecosystems represent an integrated unenclosed part of the biosphere that communicates with the other parts and through a continuous exchange of matter, energy, and information. It is an essential component of a functional unit of living nature on our planet. The meaning of each part can be only understood if it is considered as a unit.

Obviously, human beings are also a part of the landscape ecosystems [20] that provide them with many benefits identified as goods and ecosystem services. While the goods are produced by the ecosystem and represent specific things or environmental components necessary for life (such as food, water, wood, and fuel), ecosystem services are understood as different regulating mechanisms, as well as water supply for ecosystems, ensuring natural waste recycling, etc., human beings often don't realize their value. Because people take these services and goods as a matter of course without determining their market price or value, and indeed a significant part of them is available for free, during the last decade scientists and politicians have been trying to incorporate their fair value within economic mechanisms so as to ensure effective management [21]. Economic assessment and valuation of ecosystem services in protected areas is based on the concepts of conservation biology and ecology as well as ecological economics [22]. The ecosystem services valuation is based on the work of Costanza et al. [2], The Value of the World's Ecosystem Services and Natural Capital, which the work of various experts predates. The green economy that created preconditions to ensure green growth was gradually developed in the meaning of current conceptions of UN, the Organization for Economic Co-operation and Development (OECD), and the EU.

NATURA 2000 provides conservation of biodiversity and also offers a wide spectrum of social and economic advantages; it includes more than 25,000 protected sites in Europe. The direct benefits offered by these sites include tourism and recreation, as well as ecosystem services such as erosion protection, water purification, pollination, etc. However, the member states are responsible for taking precautionary measures to ensure and protect the sites and avoid their degradation.

EU priority until 2020 is to preserve and strengthen the ecosystems and their services, to restore at least $15 \%$ of degraded ecosystems by incorporating a green infrastructure to the planning [23] and sustainable regional development, linking cohesion, heritage conservation, and balanced competitiveness, is the main objective of the European Spatial Development Perspective (ESDP) [24-25]. In Slovakia, it is necessary to focus on adequate ecosystem services valuation and economic costs and benefits assessment of protected areas. Therefore, in this context the support of incorporating these values into green accounting and reporting not only at national level, but also at the EU level is a subsequent partial objective by 2020 . For that purpose, within the EU has been established a Working Group on Mapping and Assessment of Ecosystems and their Services (MAES), which is tasked with implementing determined objectives by time-limited measures and steps of common framework to involve the European Commission, Member States, and also the most important stakeholders and society [23, 26]. Besides the above-mentioned objectives, the strategy includes a vision that until 2050, a natural capital (including ecosystem services) should be protected and valued in order to prevent catastrophic changes caused by their loss. Therefore, the ecosystem services should be restored appropriately in terms of their value and significant contribution to the human well-being and sustainable economic development.

Our overall goal is to explore the 'recreational ecosystem services' in the context of the socioecological system through linkages between subsystems of natural, social, and built capital. The overall motivation is to better understand how concepts of well-being and ecosystem services can be related to everyday life and resource use in a rural community and the ecosystem within which it is imbedded. We take an interdisciplinary approach and see ecosystem services and benefits as being constituted through interactions between nature and society.

\section{Materials and Methods}

The main objective of our presented article is a valuation of selected ecosystem services (especially cultural services) in SCI Vtáčnik (NATURA 2000). Used methodology is based on guidelines for rapid assessment of Ecosystem Services Valuation in Carpathian Protected Areas [27-28] and Millennium Ecosystem Assessment [29-30]. A questionnaire survey directly on-site was conducted from April to October 
2015 at the most frequent localities of the SCI Vtáčnik (SKUEV0273). The questionnaire (24 open, half open, and closed questions) is focused on finding preferences of the visitors and their willingness to pay (WTP) an entry fee to the protected area (PA), and a willingness to accept (WTA) certain restrictions for the development and for a brand of SCI Vtáčnik. The questionnaire was developed to also ascertain visitors' demographic and socio-economic information. We have calculated the recreational value (VRT) of SCI Vtáčnik through the scheme VRT $=\mathrm{Sm} * \mathrm{DM} * \mathrm{NV}$, where $\mathrm{Sm}(\mathrm{EUR})$ is average value of expenditures per person per day, DM is average length of stay, and NV is average number of visitors.

A total of 309 respondents participated in this survey. The return rate of the questionnaire was $61.8 \%$ in the number of 500 distributed copies. Participants came from various grade levels of education $(51 \%$ master's degrees, 36\% secondary school graduates, $6 \%$ finishers from apprentice education, $7 \%$ primary school graduates) and various jobs (28\% students, $29 \%$ self-employed, $10 \%$ parents on "mother care," $9 \%$ workers, 4\% unemployed and pensioners, 8\% government employees and others). Female participants were predominant $(55 \%)$, and the following races and ethnicities were represented in the sample: $99 \%$ Slovak, 1\% Czech. Average age of participants was $30.6($ median $=28, \mathrm{SD}=13.26, \mathrm{CV}=43.43 \%)$. For final evaluations we used the statistics: Descriptive Methods - Summary Statistics $(\mathrm{M}=$ Mean, $\mathrm{SD}=$ Standard Deviation, Median, cv = coefficient of variation) by software STATGRAPHICS v. 5.0.

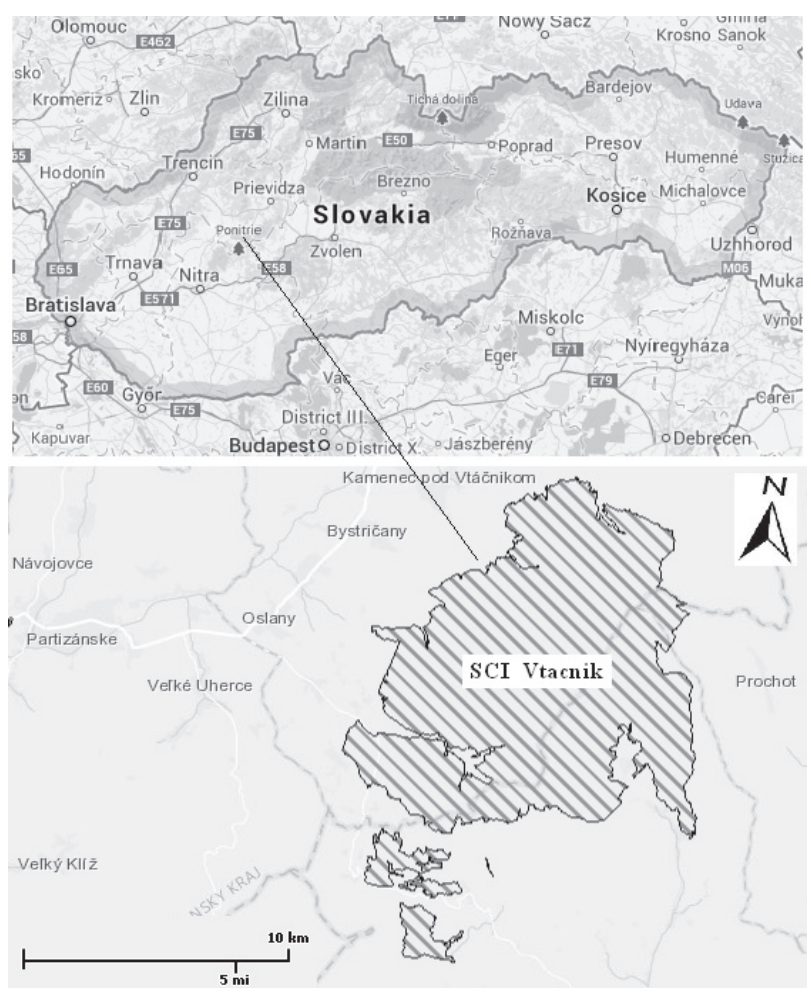

Fig. 1. Map of recreational sites in the evaluated area.

\section{Study Area}

The Vtáčnik Mountains is a mountain range with the highest peak named Vtáčnik (1346 m a.s.1.), which forms part of the Slovak Central Mountains (Slovenské stredohorie) within the Inner Western Carpathians (Fig. 1.). The mountain range covers an area of $356 \mathrm{~km}^{2}$ specified by coordinates $48^{\circ} 37^{\prime} 28^{\prime \prime} \mathrm{N}$ and $18^{\circ} 38^{\prime} 3^{\prime \prime} \mathrm{E}$.

Recreational sites are located only on the periphery of the evaluated area as they are incompatible with the reasons declaring the areas in the context of the European network of protected areas NATURA 2000, and that priority is to protect habitats and species of European importance. The recreational objects in the area are with a small or medium capacity, located in the valleys surrounding the mountains; they have seasonal or year-round used with a possibility of hiking, biking, climbing, picking forest fruits, and skiing.

\section{Results and Discussion}

Life in Protected Area Ponitrie has evolved in a demanding natural environment through a challenging way of life based on tourism. However, the very demands of this human-environment interaction are also a key component of the sense of identity and social cohesion [31], and hence community capacity to adapt to a changing future [32-33]. Provisioning and cultural ecosystem services are deeply intertwined and are perceived to be fundamental to well-being through the ecosystem (resources, economy, jobs, land- and seascapes for sustenance and recreation) and their contribution to social cohesion and human resources (heritage, land use traditions, local skills, norms, identity) [11, 30, 33-34]. According to the management of Protected Area Ponitrie, a gross estimate of visiting, when the area is the most popular by tourists, depends on locality, season, and day of the week. This means approximately 16,000 visitors per year in SCI Vtáčnik. The proliferation of recreational and tourism activities in the Vtáčnik Mountains is significantly lower in comparison to other protected areas in Slovakia. The main reasons may include a weak awareness of the area as well as the fact that the area is mainly popular as one-day tourism. Another important factor affecting a visiting the area can be the fact that a network of tourism is not adequately built up according to the area and levels of protection, so a potential of the area is staying unused. The key season for recreation in the evaluated area is the summer, when it is mainly visiting because of hiking and climbing.

According to a comparison of our research with the results of others assessing protected areas in Slovakia, where the recreational values were also evaluated by travel costs methodology and willingness to pay for specific services (WTP), there aren't bigger differences in demographic and socio-economic structure and characteristics of visitors. The average 
Table 1. Comparison of available demographic and socioeconomic statistics of visitors in protected areas (Adapted by: Považan, Getzner, Švajda [22]; Považan, [37]; Mišutová [38]).

\begin{tabular}{|c|c|c|c|c|}
\hline & SCI Vtáčnik & PA \& BR Pol’ana & Vel'ká Fatra NP & Muránska planina NP \\
\hline Number of respondents / number of visitors per year & $309 / 16,000$ & $300 / 18,000$ & $150 / 500,000$ & $472 / 30,000$ \\
\hline Gender & \multicolumn{4}{|c|}{$\%$ (number of respondents) } \\
\hline Females & $55(171)$ & $56(167)$ & $47(70)$ & $48(225)$ \\
\hline Males & $45(138)$ & $44(133)$ & $53(80)$ & $52(243)$ \\
\hline Age of respondents (average) & 30.60 & 33.90 & 35.71 & 38.00 \\
\hline Number of members per household (average) & 3.75 & 3.23 & 3.38 & 2.83 \\
\hline The highest level of education & \multicolumn{4}{|c|}{$\%$ (number of respondents) } \\
\hline Primary schools finishers & $7(21)$ & $8(23)$ & $7(11)$ & $3(13)$ \\
\hline Secondary schools finishers & $36(111)$ & $44(133)$ & $41(62)$ & $48(222)$ \\
\hline finishers of apprentice education & $6(18)$ & $0(0)$ & $3(4)$ & $8(35)$ \\
\hline Master's degree & $51(159)$ & $47(144)$ & $49(73)$ & $41(187)$ \\
\hline Present profession & \multicolumn{4}{|c|}{$\%$ (number of respondents) } \\
\hline Student & $28(87)$ & $28(84)$ & $20(29)$ & $12(58)$ \\
\hline housewife/man, parents on mother care & $10(33)$ & $4(12)$ & $0(0)$ & $4(18)$ \\
\hline Unemployed & $4(12)$ & $6(17)$ & $2(2)$ & $5(22)$ \\
\hline Pensioner & $4(12)$ & $3(10)$ & $7(11)$ & $8(37)$ \\
\hline Worker & $9(27)$ & $2(64)$ & $17(26)$ & $14(69)$ \\
\hline Government employer & $8(24)$ & $15(45)$ & $18(27)$ & $21(96)$ \\
\hline Employer in private sector & $22(69)$ & $15(45)$ & $23(35)$ & $21(96)$ \\
\hline Businessman & $7(21)$ & $8(23)$ & $13(20)$ & $15(72)$ \\
\hline Others & $8(24)$ & $0(0)$ & $0(0)$ & $0(0)$ \\
\hline Income per household & \multicolumn{4}{|c|}{$\%$ (number of respondents) } \\
\hline Less than $500 €$ & $18(54)$ & $6(17)$ & $10(15)$ & $13(59)$ \\
\hline $500 €-1000 €$ & $22(69)$ & $40(121)$ & $34(51)$ & $48(214)$ \\
\hline $1000 €-1250 €$ & $19(60)$ & $29(87)$ & $13(20)$ & $9(42)$ \\
\hline $1250 €-1500 €$ & $18(54)$ & $10(30)$ & $13(20)$ & $8(37)$ \\
\hline More than $1500 €$ & $23(72)$ & $15(45)$ & $30(44)$ & $22(98)$ \\
\hline
\end{tabular}

number of household members was approximately the same for all four comparing studies, which means 3-4 persons, including one member as a child younger than 18 years old. The economic situation in households was comparable to the national average, where a net income per three-member family is approximately $€ 1,100$ (Table 1). However, it is necessary to realize that this information has only an indicative character and does not affect the valuation of recreational services in the evaluated area.

\section{Main Tasks and Activities of Visitors}

Important factors affecting tourism in the area are activities that visitors can provide during their stay, and they are often a reason for its visit. According to the survey, SCI Vtáčnik is mostly visited because of hiking (43\%). We present the details of other surveys (Table 2) as comparison, where it is clearly shown that in PA and BR Polana (Slovakia) similar activities like in our assessed area dominate. Ament et al. [35] found that the most-valued cultural services of protected areas were spread over all cultural ecosystem service (CES) subcategories [32] in South African national parks:

1) Natural history.

2) Recreation.

3) Sense of place.

Our results confirmed the conclusions of Kruger and Saayman [36] and Ament et al. [35] that visitors to protected areas have distinct travel motivations, 
Table 2. Details of the main visitors activities in PA and BR Pol'ana and Muránska Planina NP (Adapted from: Považan, Getzner, Švajda [22]; Mišutová [38]).

\begin{tabular}{|c|c|c|c|}
\hline & $\begin{array}{c}\text { SCI Vtáčnik } \\
\text { (Slovakia) }\end{array}$ & $\begin{array}{c}\text { PA \& BR Pol’ana } \\
\text { (Slovakia) }\end{array}$ & $\begin{array}{c}\text { Muránska planina NP } \\
\text { (Slovakia) }\end{array}$ \\
\hline Main activities & \multicolumn{2}{|c|}{ (number of respondents) } \\
\hline Tourism & $43(258)$ & $91(273)$ & $32(150)$ \\
\hline Climbing & $6(36)$ & $8(24)$ & $23(108)$ \\
\hline Visiting exhibitions and facilities & $2(12)$ & $5(8)$ & $21(99)$ \\
\hline Fauna and flora observation & $16(93)$ & $29(87)$ & $14(68)$ \\
\hline Sport - running, cycling and others & $17(102)$ & $27(80)$ & $10(47)$ \\
\hline Cultural activities & $8(46)$ & $18(55)$ & $3(16)$ \\
\hline Visiting cottages and restaurants & $7(39)$ & $9(27)$ & $0(0)$ \\
\hline Others & $1(8)$ & $4(11)$ & \\
\hline
\end{tabular}

and managers of protected areas have to know and understand visitors base (socioeconomic backgrounds).

In terms of duration of stay, SCI Vtáčnik is mostly visited for one-day recreation and tourism, because $78 \%$ of respondents didn't plan to stay overnight. In 42 cases $(14 \%)$ visitors came for 2-day stays and half of them, 21 visitors (7\%), used the area as a long weekend stay, meaning a 3- to 4-day stay. The average number of days of staying was the lowest among the others comparing protected areas, and represents 1.38 days. In the BR Pol'ana protected area it represented 1.59 days, in national parks approximately 2.28, resp. 2.29 days.

\section{Recreational Value}

To calculate the recreational value of the area requires an estimate of total travel costs of visitors spending for individual services or activities; therefore we could calculate the average costs for services per visitor (Table 3) based on presented mean values of recreational costs of visitors of $€ 37.14$ per person/day, including all categories. We only take into account the costs related particularly to a visit of the area to calculate recreational value of the assessed area (marked in green color in Table 4), which means transport and other costs and local taxes; a mean value represents approximately $€ 9.61$ per person and per day.

$$
\begin{gathered}
\text { Recreational value (VTR) in SCI Vtáčnik } \\
\text { VRT }=\mathrm{Sm} * \mathrm{DM} * \mathrm{NV}=37.14 * \\
1.38 * 16,000=€ 820,051.2 \\
(\mathrm{VTR}-\text { into account all costs) } \\
\mathrm{VRT}=\mathrm{Sm} * \mathrm{DM} * \mathrm{NV}=9.61 * \\
1.38 * 16,000=€ 212,188.8 \\
(\mathrm{VTR}-\text { into account transport costs only) }
\end{gathered}
$$

Notes: Sm $(€)$ : average value of expenditures per person per day, DM: average length of stay, NV: average number of visitors

Despite the fact that the estimated number of tourists

\begin{tabular}{|c|c|c|c|c|c|c|c|c|}
\hline & $0 €$ & $1-5 €$ & $6-10 €$ & $11-15 €$ & $16-20 €$ & $21-25 €$ & $>25 €$ & average $€$ \\
\hline Food & 60 & 69 & 78 & 45 & 36 & 12 & 9 & 8.30 \\
\hline Accommodation & 240 & 2 & 6 & 14 & 12 & 20 & 15 & 4.16 \\
\hline Shopping & 135 & 63 & 33 & 33 & 18 & 12 & 15 & 6.00 \\
\hline Expenses & 129 & 84 & 42 & 30 & 24 & 0 & 0 & 4.56 \\
\hline Sport & 174 & 54 & 54 & 21 & 6 & 0 & 0 & 3.15 \\
\hline Museums & 171 & 75 & 51 & 12 & 0 & 0 & 0 & 2.55 \\
\hline Transport & 104 & 177 & 24 & 4 & 0 & 0 & 0 & 2.50 \\
\hline Others & 153 & 45 & 39 & 36 & 21 & 15 & 0 & 5.92 \\
\hline
\end{tabular}
visiting the area is relatively small and an average duration of stay is shorter (one-day tourism dominates), recreational values of our assessed area are not the lowest in comparison with others studies in Slovakia (Table 4.).

Table 3. Average of visitors expenses per person and per day during their stays in the area. 
Table 4. Comparison of VTR in SCI Vtáčnik with other PAs in Slovakia (adapted from: Mišutová [38]; Považan, [37]; Považan, Getzner, Švajda [22]).

\begin{tabular}{|c|c|c|c|c|}
\hline & $\begin{array}{c}\text { SCI } \\
\text { Vtáčnik }\end{array}$ & $\begin{array}{l}\text { PA \& BR } \\
\text { Pol'ana }\end{array}$ & Vel'ká Fatra NP & $\begin{array}{c}\text { Muránska } \\
\text { planina NP }\end{array}$ \\
\hline Total area (ha) & $10,056.59$ & 20,360 & 40,371 & 20,318 \\
\hline Number of visitors per year & 16,000 & 18,000 & 500,000 & 30,000 \\
\hline Average duration of stay (days) & 1.38 & 1.59 & 2.28 & 2.29 \\
\hline Average costs per person/per day & $€$ & $€$ & $€$ & $€$ \\
\hline food & 8.30 & 14.80 & 13.10 & 23.89 \\
\hline accommodation & 4.16 & 11.60 & 8.60 & 15.73 \\
\hline shopping & 6.00 & 5.40 & 4.40 & 8.24 \\
\hline fees & 4.56 & 4.10 & 1.80 & 3.92 \\
\hline sport & 3.15 & 3.50 & 4.30 & 2.26 \\
\hline museums & 2.55 & 1.60 & 1.70 & 1.78 \\
\hline transport & 2.50 & ---- & 5.80 & 2.08 \\
\hline others & 5.92 & 5.90 & 6.80 & 7.46 \\
\hline $\begin{array}{l}\text { SUM } \\
\text { average expenses/day }\end{array}$ & 37.14 & 46.90 & 46.50 & 65.36 \\
\hline Recreational value of area calculated per 1 ha & 81.54 & 65.93 & 1313.07 & 210.63 \\
\hline $\begin{array}{l}\text { Average expenses related to visiting the area per day } \\
\text { (according to expenses related to visit the area directly) }\end{array}$ & 9.61 & 5.70 & 9.30 & 7.78 \\
\hline $\begin{array}{l}\text { Recreational value according to transport costs only, related to visit } \\
\text { of the area per } 1 \text { ha }\end{array}$ & 21.10 & 8.01 & 262.61 & 25.07 \\
\hline
\end{tabular}

\section{Willingness-to-pay (WTP) for Management in SCI Vtáčnik}

The last question of the questionnaire was hypothetical and focused on willingness to pay an entrance fee to the protected area, which would be used for ensuring particular management measures for sustainability of SCI Vtáčnik; while respondents were shown that financial contributions by government are reduced and are often inadequate, so their willingness to pay an entrance fee would go beyond other expenses.

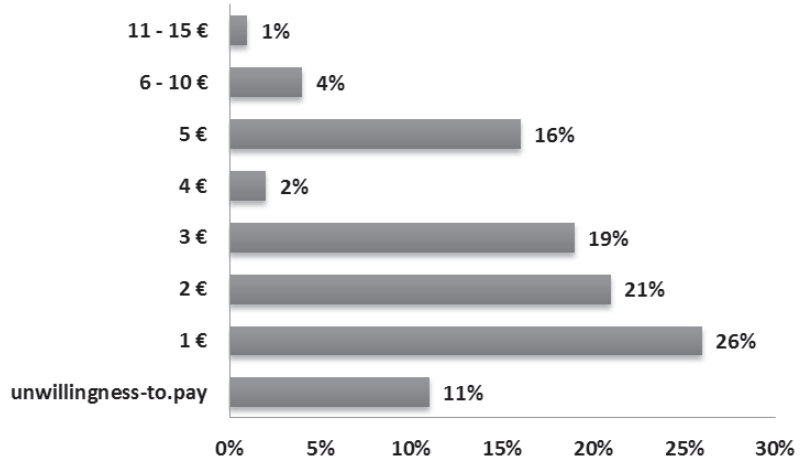

Fig. 2. Willingness-to-pay of the visitors (WTP) for entry to SCI Vtáčnik.
The percentage of the amount for entrance fee that visitors would be willing to pay for supporting the development and nature conservation in our assessed protected area is presented in Fig. 2. The average amount that visitors would be willing to pay as an entrance fee to SCI Vtáčnik is $€ 2.56$ per person, which is comparable with the results of PA and BR Polana, where the amount was about 30 cents higher $(€ 2.83)$. According to Považan, Getzner, and Švajda [37], the respondents in NP Muránska planina (Slovakia) would be willing to pay, beyond other expenses, €3.67 as an entrance fee.

\section{Conclusions}

The main tasks of the presented contribution was evaluating ecosystem services resulting from recreational activities in SCI Vtáčnik, with mean annual visiting of 16,000 tourists. As we had supposed before, a recreational value of the area would be lower than in national parks, whose management was assessed by a similar survey because of the area size $(10,056.59 \mathrm{ha})$, the number of visitors, the length of stay, and expenses spent by respondents. The 24-question questionnaire gave us received responses of 309 respondents, where we determined that the average duration of their stay was 1.38 days, then expenses of respondents represented 
the value of $€ 51.25$ per person/stay. According to the survey and subsequent calculations of all costs in SCI Vtáčnik, we quantified recreational value at $€ 820,051.2$, which was converted tol ha of PA at $€ 81.54$. If we take into account transport costs only, the mean value of recreational benefits (VTR) would amount to $€ 212,188.8$, and if converted to 1 ha of the evaluated area the value would be $€ 21.10$.

Tourists have become more sensitive to the environment, the unique qualities of cultures, and the contribution of their spending to a better quality of life for those most vulnerable. Our study has shown that $89 \%$ of respondents prefer the development of green tourism, so we recommend:

1) Focusing management of SCI Vtáčnik to sustainable tourism occurring at the community levels and better understanding of ecosystem services related to wellbeing and their needs to include broad concepts of human-nature interactions.

2) Future management plans should include the development of a community-owned ecotourism enterprise that follows operational ecosystem service concepts that must also include elements of social and built capital, and their dependence on local natural capital.

We have chosen this emphasis because it not only is at this level where tourism occurs, but this scale is where the action is, where development occurs, and where people interact to get things done. Management actions seeking to amplify a particular kind of CES, or improve access to that CES, are more likely to achieve their goals if they align with the specific properties of local ecosystems and locally specific tourist demand.

SCI Vtáčnik has natural availability, and thus high demands for, natural history-type CES could increase their economic viability through greater investment in educational and viewing resources, such as species lists, birds, and vegetation maps; and the evaluated protected area also has greater capabilities to deliver recreationaltype CES so that it may invest in activities on offer (e.g., mountain bike tours) or equipment hire (e.g., bicycles). These management actions would have strong practical implications, particularly where protected area viability depends on economic returns from tourism.

\section{Conflict of Interest}

Each of the authors declares no conflict of interest.

\section{References}

1. DIAZ S., DEMISSEW S., JOLY C., LONSDALE W.M., LARIGAUDERIE A. A Rosetta stone for nature's benefits to people. PLoS Biology, 13 (1), 1, 2015.

2. CONSTANZA R., D'ARGE R., DE GROOT R.S., FARBER M., GRASSO M., HANNON B., LIMBURG K., NAEEM S., O'NEILL R.V., PARUELO J., RASKIN R.G., SUTTON P., VAN DEL BELT M. The Value of the
World's Ecosystem Services and Natural Capital. Nature, 387, 253, 1997.

3. TURNER R.K., DAILY G.C. The ecosystem services framework and natural capital conservation. Environmental and Resources Economics, 39, 25, 2008.

4. GÓMEZ-BAGGETHUN E., RUIZ-PÉREZ M. Economic valuation and the commodification of ecosystem services. Progress in Physical Geography, 35, 613, 2011.

5. KALTENBORN B.P., LINNELL J.D.C., BAGGETHUN E.G., LINDHJEM H., THOMASSEN J., CHAN K.M. Ecosystem Services and Cultural Values as Building Blocks for 'The Good life'. A Case Study in the Community of Røst, Lofoten Islands, Norway. Ecological Economics, 140, 166, 2017.

6. CARPENTER S.R., BENNETT E.M., PETERSON G.D. Scenarios for ecosystem services: an overview. Ecology and Society, 11, 29, 2006.

7. DANIEL T.C., MUHAR A., ARNBERGER A., AZNAR O., BOYD J.W., CHAN K.M.A., CONSTANZA R., ELMQVIST T., COURTNEY G.F., GOBSTER P.H., GRET-REGAMY A., LAVE R., MUHAR S., PENKER M., RIBE R.G., SCHAUPPENLEHNER T., SIKOR T., SOLOVIY I., SPIERENBURG M., TACZANOWSKA K., TAM J., VON DER DUNK A. Contributions of cultural services to the ecosystem services agenda. PNAS, 109, $8812,2012$.

8. DE GROOT R.S., ALKEMADE R., BRAAT L., HEIN L., WILLEMEN L. Challenges in integrating the concept of ecosystem services and values in landscape planning, management and decision making. Ecological Complex, 7, 260, 2010.

9. KAREIVA P., TALLIS H., RICKETTS T.H., DAILY G.C., POLASKY S. Natural Capital: Theory \& Practice of Mapping Ecosystem Services, Oxford University Press: Oxford, England, 256 pp., 2011.

10. NAHUELHUAL L., CARMONA A., LATERRA P., BARRENA J. A mapping approach to assess intangible cultural ecosystem services: the case of agriculture heritage in Southern Chile. Ecol. Indic., 40, 90, 2014.

11. SATTERFIELD T., GREGORY R., KLAIN S., ROBERTS M., CHAN K.M. Culture, intangibles and metrics in environmental management. Journal of Environmental Management, 117, 103, 2013.

12. SYRBE R., WALZ U. Spatial indicators for the assessment of ecosystem services: providing, benefitting and connecting areas and landscape metrics. Ecological Indicators, 21, 80, 2012.

13. VAN BERKEL D.B., VERBURG P.H. Spatial quantification and valuation of cultural ecosystem services in an agricultural landscape. Ecological Indicators, 37, 163, 2014.

14. FARBER S.C., CONSTANZA R., WILSON M.A. Economic and ecological concepts for valuing ecosystem services. Ecological Economics, 41, 375, 2002.

15. CONSTANZA R., FISHERA B., ALIB S., BEERC C., BONDD L., BOUMANSA B., DANIGELISE N.L., DICKINSON J., ELLIOTTC C., FARLEYA J., GAYERG D.E., MACDONALD GLENNH L., HUDSPETH T., MAHONEY D., MCCAHILL L., MCINTOSH B., REED B., TURAB RIZVI S.A., RIZZO D.M., SIMPATICO T., SNAPP R. Quality of life: an approach integrating opportunities, human needs, and subjective well-being. Ecological Economics, 61, 267, 2006.

16. WELSCH H. Implications of happiness research for environmental economics. Ecological Economics, 68, 2735,2009 
17. TENGBERG A., FREDHOLM S., ELIASSON I., KNEZ I., SALTZMAN K., WETTERBERG O. Cultural ecosystem services provided by landscapes: assessment of heritage values and identity. Ecosystem Services, 2, 14, 2012.

18. CHAN K.M.A., GUERRY A.F., BALVANERA P., KLAIN S., SATTERFIELD T., BASURTO X., BOSTROM A., CHUENPAGDEE R., GOULD R., HALPERN B.S., HANNAS N., LEVINE J., NORTON B., RUCKELSHAUS M., RUSSELL R., TAM J., WOODSIDE U. Where are cultural and social in ecosystem services? A framework for constructive engagement. Bioscience, 62, 744, 2012.

19. CHAN K.M.A., SATTERFIELD T., GOLDSTEIN J. Rethinking ecosystem services to better address and navigate cultural values. Ecological Economics, 74, 8, 2012.

20. MASNÝ M., ZAUŠKOVÁ L'. The abandonment of agricultural land: A case study of Strelníky (The Pol'ana Biosphere Reserve - Slovakia). Carpathian Journal of Earth and Environmental Sciences, 9, 17, 2014.

21. EUROPEAN COMMISSION. The Economics of ecosystems \& biodiversity: An interim report. Office for Official Publications of the European Communities: Luxembourg, Luxembourg, 68 pp., 2008.

22. POVAŽAN R., GETZNER M., ŠVAJDA J. On the valuation of ecosystem services in Muránska Planina National Park. EcoMont, 7, 61, 2015.

23. EUROPEAN COMMISSION. Mid - term evaluation of the EU Biodiversity Strategy by the year 2020. Ecosystems LTD.: Brussels, Belgium, 16 pp., 2016.

24. ANCUTA C., OLARU M., POPA N., ISFANESCU R., JIGORIA-OPREA I., JIGORIA-OPREA L. Evaluation of the sustainable development of rural settlements. Case study: Rural settlements from Romania Banat. Carpathian Journal of Earth and Environmental Sciences, 10, 67, 2015.

25. BOLE D., PIPAN P., KOMAC B. Cultural values and sustainable rural development: A brief introduction. Acta Geographica Slovenica, 53, 367, 2013.

26. MAES J., TELLER A., ERHARD M., LIQUETE C., BRAAT L., BERRY P., EGOH B., PUYDARRIEUX P., FIORINA C., SANTOS F., PARACCHINI M.L., KEUNE H., WITTMER H., HAUCK J., FIALA I., VERBURG P.H., CONDÉ S., SCHÄGNER J.P, SAN MIGUEL J., ESTREGUIL C., OSTERMANN O., BARREDO J.I., PEREIRA H.M., STOTT A., LAPORTE V., MEINER A., OLAH B., ROYO G.E., SPYROPOULOU R., PETERSEN J.E., MAGUIRE C., ZAL N., ACHILLEOS E., RUBIN A., LEDOUX L., BROWN C., RAES C., JACOBS S., VANDEWALLE M., CONNOR D., BIDOGLIO G.
Mapping and Assessment of Ecosystems and their Services: An analytical framework for ecosystem assessments under Action 5 of the EU Biodiversity Strategy to 2020. Publications office of the European Union: Luxembourg, Luxembourg, 188 pp., 2013.

27. BUCUR C., STROBEL D. Valuation of Ecosystem Services in Carpathian Protected Areas - Guidelines for rapid assessment. Green Steps: Brasov, Romania, 38, 2011.

28. POVAŽAN R., KADLEČÍK J. Valuation of Ecosystem services in Carpathian Protected Areas with focus on Slovakia - Guidelines for rapid assessment. State Nature Protection of Slovak republic: Banska Bystrica, Slovak republic, 38 pp., 2014.

29. Millennium Ecosystem Assessment. Ecosystem and Human Well-being: A framework for assessment, Island Press: Washington, DC., USA, 266, 2003.

30. Millennium Ecosystem Assessment. Ecosystem and Human Well-being : Synthesis. Island Press: Washington, DC., USA, 258, 2005.

31. KUMAR M., KUMAR P. Valuation of the ecosystem services: a psycho-cultural perspective. Ecological Economics, 64, 808, 2008.

32. MA. Ecosystem and human well-being: synthesis. Island Press: Washington, DC., USA, 155 pp., 2005.

33. SATZ D., GOULD R.K., CHAN K.M., GUERRY A., NORTON B., SATTERFIELD T., HALPERN B.S., LEVINE J., WOODSIDE U., HANNAHS N., BASURTO X., KLAIN S. The challenges of incorporating cultural ecosystem services into environmental assessment. Ambi., 42, 675, 2013.

34. GOULD R.K., KLAIN S.C., ARDOIN N.M., SATTERFIELD T., WOODSIDE U., HANNAHS N., DAILY G.C., CHAN K.M. A protocol for eliciting nonmaterial values using a cultural ecosystem services frame. Conservation Biology, 29, 575, 2015.

35. AMENT J.M., MOORE CH.A., HERBST M., CUMMING G.S. Cultural Ecosystem Services in Protected Areas: Understanding Bundles, Trade-Offs, and Synergie. Conservation Letters, 10, 440, 2017.

36. KRUGER M., SAAYMAN M. Travel motivation of tourists to Kruger and Tsitsikamma National Parks: a comparative study. S. Afr. J. Wildl. Res., 40, 93, 2010.

37. POVAŽAN R. Recreational values NP Vel'ká Fatra (Slovakia). Acta Universitatis Matthiae Belii, 15, 82, 2013.

38. MIŠUTOVÁ B. Economic evaluation of ecosystem services in the protected area: master thesis. Matej Bel University: Banska Bystrica, Slovakia, 78 pp., 2015. 